\title{
A Research on Rotifers of Aquatic Ecosystems of Kashmir Himalaya for Documentation and Authentication
}

\author{
Javaid Ahmad Shah • Ashok Kumar Pandit • \\ G. Mustafa Shah
}

Received: 5 August 2013/Revised: 30 January 2014/ Accepted: 28 February 2014/Published online: 22 March 2014

(C) The Author(s) 2014. This article is published with open access at Springerlink.com

\begin{abstract}
The wheel animalcules, belonging to minor phylum Rotifera are the most important soft-bodied invertebrate pseudocoelomates, bilaterally symmetrical, metazoan protostomes ranging from 50 to $2,000 \mathrm{~mm}$ in size with three regions (corona, trunk and foot) in the body. Phylum Rotifera with cosmopolitan distribution has an estimate of about 2,030 identified species. Because of their great importance in the aquatic ecosystems, the existing literature on rotifers is quite considerable worldwide, yet comparatively scanty literature is available on the taxonomy and distribution of rotifers of Kashmir Himalaya. Therefore, in the present article an attempt has been made to document the historical review of rotifers of Kashmir Himalayan waters.
\end{abstract}

Keywords Rotifera - Taxonomy · Composition ·

Kashmir Himalaya $\cdot$ India

\section{Introduction}

The valley is a unique natural region, lying within the north western tip of oriental region abutting the Palaearctic region, between $33^{\circ} 25^{\prime}-34^{\circ} 50 \mathrm{~N}^{\prime}$ and $74^{\circ}-75.5^{\prime} \mathrm{E}$. In the western Himalaya, the high altitude valley of Kashmir abounds in a vast array of freshwater bodies including lakes, wetlands, springs and streams [1-3].

\section{J. A. Shah $(\bowtie) \cdot$ A. K. Pandit}

Centre of Research for Development (CORD), University of

Kashmir, Srinagar 190006, J\&K, India

e-mail: javaidshah31@gmail.com

G. M. Shah

Department of Zoology, University of Kashmir, Srinagar 190006, J\&K, India
Among these the lentic ecosystem (lakes and wetlands) assume significant importance in being greater repository of freshwater biodiversity which is generally understood largely due to the result of increasing human pressure [4-7]. Rotifers were first studied by Leuwenhoek in the year 1703. Rotifers are pseudocoelomate living creatures, ranging from 50 to $2,000 \mathrm{~mm}$ in size. It is one of the oldest groups of invertebrates in nature [8]. The general body plan of a rotifer consists of three basic regions (corona, trunk and foot). In many species corona consists of trochus and cingulum (two rings of cilia that beat in a metachronous pattern). The trunk is divisible into five parts namely mouth, mastax, stomach, intestines and anus while the foot consists of pseudo segments and toes $[9,10]$.

They have achieved more significance in freshwater by residing in littoral, limnetic and benthic regions [11-13], and most of them are cosmopolitan in distribution [14, 15]. The phylum Rotifera comprises approximately 2,030 described freshwater species from the world [16]. It has been divided into three classes: Monogononta $(1,570$ species) being entirely parthenogenetic, Bdelloidea (460 species), and Seisonidea with a few species (two known genera with three species). Former two have been recognized as freshwater classes and the latter one as marine [16-19]. Rotifers play a major role in energy relocation and nutrient cycling [20], and are often used as bioindicators of water pollution [21-23]. The community composition and density of rotifers greatly varies with degree of eutrophication [24, 25]. They have also been reported as bioassay animals [26]. Further, rotifers have gained great ecological importance in aquatic environments by adopting the method of filter feeding by consuming and incorporating different types of food resources of different sizes $[13,27,28]$. 
Taxonomic Survey of Rotifera in India

According to a conservative estimate, there are over 500 species of rotifers in Indian water bodies, although only 330 species belonging to 63 genera and 25 families have so far been authenticated [29]. Segers and Babu [30] and Sharma and Sharma [31] have added 5 new taxa to the Indian checklist. Taxonomic work in India was initiated by Anderson [32] who listed ten new species from Calcutta while Murray [33] listed 32 species from the Sikkim Himalaya. In another survey, Steward [34] reported 17 species from trans-Himalayan region. During the Yale of North India Expedition, Edmondson and Hutchinson [35] reported 100 species including 13 species of the family Lecanidae from different localities of India. Ahlstrom [36] described two new species, Keratella quadrata var. edmondosoni and $K$. quadrata var. pyriformis from Madras. Nayar and Nair [37] described 15 brachionid rotifers first time from Kerala with four new reports as Brachionus forficula keralaiensis, Dipeuchlanis propatula, Anuraepsis fissa lata and B. caudatus personatus). Nayar [38] while studying Rotifer fauna of Rajasthan reported 36 species, of which 14 species were reported for the first time in India including one new species.

Other notable contributions in this field were that of Naidu, [39], Vasisht and Gupta [40], Vasisht and Battish [41, 42] and Sharma, [43-48]. However, Sharma and Micheal $[49,50]$ prepared a taxonomic list of Indian rotifers by extensive surveys from different parts of the country but the species exiting in Kashmir Himalaya were not fully explored though later on Wanganeo and Wangeneo [51] and Pandit [52] have provided a detailed list of rotifer species from the Kashmir Himalayan region (Table 1). Sharma and Micheal [49] confirmed the presence of 241 species of rotifers from the Indian subcontinent. Subsequently, 60 more species have been added to the list [52-55].

\section{Seasonal Variation in Rotifer Community}

Environmental variation is one of the fundamental factors that determines the life patterns of an organism. Temperature is one among of the prominent factors governing the chemistry of surrounding environment [56]. Therefore, species to remain alive must adopt the broad range of different environmental conditions. As a result certain conditions become maladaptive for many species or adoptive for remaining species, the adaptability giving rise to different seasonal succession patterns [57]. Seasonal variation of rotifers were studied by various authors in Kashmir and different parts of India. [4, 58-60]. However, the research scenario of rotifers in Kashmir is fully not well established and majority of the reports pertain to only spatial and temporal variations.
Taxonomic survey of rotifers in Kashmir was started by Edmondson and Hutchinson [35] who reported only eight species from lake Manasbal. After the gap of more than three decades, taxonomic work was reinitiated by Das [61], Das and Akhtar [62] and Zutshi et al. [63] who while studying the comparative limnology of nine lakes of Jammu and Kashmir reported that rotifers were the main component of the zooplankton community, Keratella cochlearis being the dominant species, among the 16 taxa reported while Ascomorpha eucaudis showed restricted distribution to only one biotope (Dal lake). Kaul et al. [64] reported 18 rotifer species from the freshwater bodies of Jammu and Kashmir, highest being recorded from sewage pond, with the dominance of Brachionus calyciflorus, reflecting high tolerance limit towards pollution. In another study Zutshi et al. [65] found only one species (Euchlanis dilatata) in spring and summer season. Seasonal abundance of rotifera in lake Manasbal was carried out by Yousuf and Qadri [66, 67] who reported 38 species of rotifers belonging to eleven families, with varied population peaks in littoral zones, while bimodal pattern of population growth (late summer-early autumn and late winter-early spring) was recorded in the limnetic stations. Zutshi and Vass [68] reported 37 species of rotifers among 93 zooplankton species in Dal lake showing maximum population density in spring and late summer. In Mirgund wetland Rotifera emerged as the most dominant group in terms of both taxa and population [69]. Euchlanis dilatata was the most dominant rotifer species among 18 species of rotifers. Khan [70] reported 27 rotifers, among 51 taxa of zooplankton, exhibiting bimodal population peaks throughout the study. A detailed hydrobiological study of Anchar lake was carried by Balkhi et al. [71] reporting 41 species of rotifers, with Asplanchna priodonta being the most dominant species. Pandit and Qadri [72] while studying the wetlands of Kashmir opined that severe floods often lead to increase in rotifers particularly Brachionus sp. and Keratella sp.

Pandit [4] while studying trophic structure of plankton community in some typical wetlands of Kashmir reported 141 species of zooplankton, of which 29 belonged to rotifera. The author opined that rotifers contribute very low towards the zooplankton standing crop as compared to crustacea and protozoa. Mean biomass was registered highest $\left(1.22 \mathrm{mg} / \mathrm{m}^{3}\right)$ for Mirgund followed by Nowgam $\left(1.14 \mathrm{mg} / \mathrm{m}^{3}\right)$ Haigam $\left(1.04 \mathrm{mg} / \mathrm{m}^{3}\right)$ in Malgam $\left(0.84 \mathrm{mg} / \mathrm{m}^{3}\right)$ and Hokarsar $\left(0.43 \mathrm{mg} / \mathrm{m}^{3}\right)$ in a decreasing order. Among the five studied wetlands of Kashmir, Nowgam, Malgam, Hiagam, Mirgund and Hokarsar, the dominant rotifer genera were Keratella, Brachionus, Cephalodella, Monostyla, Lecane, Synchaeta, Asplanchna, Trichocera, Filina and Mytilina. Pandit and Yousuf [73] while studying the rotifer community in some Kashmir Himalayan lakes of 
Table 1 List of rotifer species recorded from freshwaters of Kashmir Himalaya: an overview

\begin{tabular}{|c|c|c|c|}
\hline Anuraeopsis fissa (Gosse 1851) & $\begin{array}{l}\text { Dicranophorus robustus (Harring and } \\
\text { Myers 1928) (s) }\end{array}$ & L. pyriformis (Daday, 1905) & $\begin{array}{l}\text { Pompholyx complanata (Gosse, } \\
\text { 1851) }\end{array}$ \\
\hline A. navicula (Rousselet 1910) (s) & Diplois sp. * & L. quadridenta (Daday 1905) & Proales sp.(s) \\
\hline $\begin{array}{l}\text { Ascomorphella volvocicola } \\
\text { (Plate 1886) (s) }\end{array}$ & Ephiphanes senta (Müller 1773). (s) & L. sympoda (Hauer 1929 & $\begin{array}{l}\text { Resticula melandocus (Gosse } \\
\text { 1887) }\end{array}$ \\
\hline $\begin{array}{l}\text { Ascomorpha eucadis (Perty } \\
\text { 1850) }\end{array}$ & Ephiphanes sp. * & Lecane sp. & $\begin{array}{l}\text { Rotaria neptunia (Ehrenberg } \\
\text { 1830) (s) }\end{array}$ \\
\hline A. saltans (Bartsch 1870) & Euchlanis calpidia (Myers 1930) & $\begin{array}{l}\text { Lepadella acuminata } \\
\text { (Ehrenberg 1834) }\end{array}$ & $\begin{array}{l}\text { Scardium longicaudum (Muller } \\
\text { 1786) (s) }\end{array}$ \\
\hline Ascomorpha sp. & E. dilatata (Ehrenberg 1832) * & L. ehrenbergi (Perty 1850) & $\begin{array}{l}\text { Synchaeta oblonga Ehrenberg } \\
1832(\mathrm{~s})\end{array}$ \\
\hline $\begin{array}{l}\text { Asplanchna priodonta (Gosse } \\
\text { 1850) * }\end{array}$ & Euchlanis sp. & L. patella (Muller 1786) & S. pectinata (Ehrenberg 1832) * \\
\hline $\begin{array}{l}\text { Asplanchna brightwelli (Gosse } \\
\text { 1850) (s) }\end{array}$ & Filinia longiseta (Ehrenberg 1834) & L. periptera (Muller 1786) & S. stylata (Wierzejski 1893) (s) \\
\hline Asplanchna sp. & F. opoliensis (Zacharias 1898) * & $\begin{array}{l}\text { L. (hemimonostyla) symoda } \\
\text { (Muller 1786) }\end{array}$ & $\begin{array}{l}\text { Sphyrias lofuana (Rousselet } \\
\text { 1910) (s) }\end{array}$ \\
\hline $\begin{array}{l}\text { Asplanchnopus multiceps } \\
\text { (Schrank 1793) }\end{array}$ & F. terminalis (Plate 1886) & $\begin{array}{l}\text { Macrochaetus collinsis (Gosse } \\
\text { 1867) }\end{array}$ & $\begin{array}{l}\text { Squatinella mutica (Ehrenberg } \\
\text { 1832) }\end{array}$ \\
\hline Bdelloidea sp.(s) & Filinia sp. & Monomrnata sp. & S. rostrum (Milne 1886) (s) \\
\hline $\begin{array}{l}\text { Brachionus bidentata* } \\
\quad \text { (Anderson 1889) }\end{array}$ & Gastropus sp. & Monostyla bulla (Gosse 1867)* & $\begin{array}{l}\text { Testudinella tetractis } \\
\quad(\text { Ehrenberg } 1830)(\mathrm{s})\end{array}$ \\
\hline $\begin{array}{l}\text { B. calyciflorus (Ehrenberg } \\
\text { 1838)* }\end{array}$ & Hexarthra mira (Hudson 1871) & $\begin{array}{l}\text { M. arcata (Harring \& Myers } \\
\text { 1926) }\end{array}$ & $\begin{array}{l}\text { T. pocillum (Bowerbank 1866) } \\
\text { (s) }\end{array}$ \\
\hline $\begin{array}{l}\text { B. caudatus (Barrois \& Daday } \\
\text { 1894) }\end{array}$ & H. intermedia (Wiszniewski 1929) (s) & $\begin{array}{l}\text { M. closterocerca (Schmarda } \\
\text { 1859) }\end{array}$ & $\begin{array}{l}\text { Trichocerca cylindrica (Imhof } \\
\text { 1891)* }\end{array}$ \\
\hline B. forficula (Wierzejski 1891) (s) & Horaella brehmi (Donner 1949)* & M. decipiens (Murray 1913) & T. insignis (Herrick 1885) (s) \\
\hline B. patulus (O. F. Muller 1786) & Kellicottia longispina (Kellicott 1879 (s) & M. harnata (Murray 1913) & \\
\hline B. plicatilis (Müller 1786) & Keratella cochlearis (Gosse 1851)* & M. lunaris (Ehrenberg 1832) * & T. longiseta (Schrank 1802) * \\
\hline $\begin{array}{l}\text { B. quadricornis (Ehrenberg } \\
\text { 1832) (s) }\end{array}$ & K. hiemalis (Carlin 1943) & $\begin{array}{l}\text { M. quadridentata (Ehrenberg } \\
\text { 1832) }\end{array}$ & $\begin{array}{l}\text { T. multicrinis (Kellicott 1897) } \\
\text { (S) }\end{array}$ \\
\hline $\begin{array}{l}\text { B. quadridentatus (Hermann } \\
\text { 1783)* }\end{array}$ & K. quadrata (Müller 1786) * & M. pyriformis (Daday 1905) & T. platessa Myers 1934. (s) \\
\hline B. rubens (Ehrenberg 1838) (s) & K. tropica (Apstein 1907) & $\begin{array}{l}\text { M. ventralis (Ryding and Rast } \\
\text { 1989) }\end{array}$ & T. porcellus (Gosse 1851) \\
\hline Brachionus sp. & K. valga (Ehrenberg 1834)* & Monostyla sp. & T. rattus (Müller 1776) \\
\hline $\begin{array}{l}\text { Cephalodella exigua (Gosse } \\
\text { 1886) (s) }\end{array}$ & $\begin{array}{l}\text { Lecane angulata (var. australiensis Koste } \\
1979 \text { (s) }\end{array}$ & $\begin{array}{l}\text { Mytilina mисronata (Müller } \\
\text { 1773)* }\end{array}$ & T. tigris (Müller 1786) (s) \\
\hline C. gibba (Ehrenberg 1830) & L. bulla (Gosse 1851) & M. ventralis (Ehrenberg 1830) & T. vernalis (Hauer 1936) (s) \\
\hline Cephalodella sp. * & L. closterocerca (Schmarda 1859) & $\begin{array}{l}\text { Notholca striata (Müller 1786) } \\
\text { (s) }\end{array}$ & T. weberi (s) (Jennings 1903) \\
\hline Chromogaster sp. & L. crepida Harring 1914 & Notholca sp. & Tricocerca sp. \\
\hline $\begin{array}{l}\text { Collotheca ornate (Ehrenberg } \\
1832)(\mathrm{s})\end{array}$ & L. depressa (Bryce 1891) & Notommata sp.(s) & $\begin{array}{l}\text { Trichotria tetractis (Ehrenberg } \\
\text { 1830) }\end{array}$ \\
\hline Collotheca sp. & L. decipiens (Murray 1913) (s) & Philodina sp. & $\begin{array}{l}\text { Trochosphaera solstitialis } \\
\text { (Thorpe 1893) }\end{array}$ \\
\hline $\begin{array}{l}\text { Colurella adriatica (Ehrenberg } \\
\text { 1831) (s) }\end{array}$ & L. elachis (Harring and Myers 1926) (s) & $\begin{array}{l}\text { Platyas patulus }(\mathrm{O} . \mathrm{F} \text {. Muller } \\
\text { 1786) }\end{array}$ & \\
\hline $\begin{array}{l}\text { C. bicuspidata (van Hofsten } \\
\text { 1909) }\end{array}$ & L. elasma (Harring \& Myers 1926) (s) & P. polycanthus Ehrenberg 1834 & \\
\hline C. obtuse (Gosse 1886) & L. flexilis (Gosse 1886) (s) & $\begin{array}{l}\text { P. quadricornis (Ehrenberg } \\
\text { 1832) }\end{array}$ & \\
\hline C. oblonga (Donner 1943) (s) & L. ludwigi (Eckstein 1893) (s) & P. euryptera ((Wierzejski 1891) & \\
\hline C. uncinata (Müller 1773) (s) & L. luna (Müller 1776) * & $\begin{array}{l}\text { Polyarthra major (Burckhardt } \\
\text { 1900) }\end{array}$ & \\
\hline
\end{tabular}


Table 1 continued

\begin{tabular}{llll}
\hline Anuraeopsis fissa (Gosse 1851) & $\begin{array}{l}\text { Dicranophorus robustus (Harring and } \\
\text { Myers 1928) (s) }\end{array}$ & L. pyriformis (Daday, 1905) & $\begin{array}{l}\text { Pompholyx complanata (Gosse, } \\
\text { 1851) }\end{array}$ \\
\hline $\begin{array}{ll}\text { Colurella sp. } \\
\text { Conochiloides sp.(s) }\end{array}$ & L. lunaris (Ehrenberg 1832) & P. remata Skorikov 1896 \\
Conochilus unicornis (Rousselet & L. ohioensis (Herrick 1885)* & P. vulgaris (Carlin 1943) \\
1892) (s) & & Polyarthra sp.
\end{tabular}

(s): Secondary source (since 1939 i.e., Keifer's Yale North Indian Expedition)

Primary source: Wanganeo and Wanganeo (51), * Pandit (52)

varied tropic status observed 98 species of rotifers. They further opined that rotifer community increased qualitatively as well as quantitatively from oligotrophic to mesotrophic then finally to eutrophy. Species which were dominated in oligotrophic lakes were Asplanchna priodonta and Kellicotia longispina, while Brachionus calyciflorus and $B$. quadridentata were significant in hypereutrophic waters of Khushhalsar lake.

Siraj et al. [74] reported 32 species of rotifers among 65 zooplanktons around floating gardens in the Dal Lake. Wanganeo et al. [75] while studying the seasonal variation of rotifers in relation to physico- chemical parameters identified 47 rotifer species, showing unimodal growth peak of density in summer and further inferred that rotifer populations showed significant positive correlation with temperature, nitrate, chloride and phosphate and negative correlation with dissolved oxygen throughout the entire study period.

\section{Relation with Abiotic Parameters}

In an aquatic ecosystem the life of biota is closely dependent on the physical, chemical and biological characteristics of water, some of which directly act as the controlling factors. Therefore, for understanding the dynamics of an organism, a population or a community, knowledge of both the organism and its environment is important [76]. Yousuf and Qadri [66] while studying seasonal abundance of rotifera in a warm monomictic lake categorized the species into perennial (Polyarthra sp., Synchaeta sp., Asplanchna sp., Monostyla sp. and Keratella sp.) and seasonal with warm stenothermal (Brachionus sp., Anuraeopsis sp.) and cold stenothermal (Filinia sp., Notholca sp., Proales sp. and Bdelloid sp.). Qadri and Yousuf [77] while studying two rotifer species Anuraeopsis fissa Gosse and Notholca acuminate Ehrn opined that the former species prefers carbonate water and a narrow range of temperature $\left(18-25{ }^{\circ} \mathrm{C}\right)$ with complete establishment of thermocoline in the lake, while the latter species was reported to be a cold stenothermal with peak population in the month of February, besides preferring high bicarbonate content (118-144.50 mg/L) with low $\mathrm{pH}$ values (7.63-7.97). Species composition and abundance of rotifer population in Anchar lake was carried out by Balkhi et al. [78] reporting 33 taxa. They categorized them into three groups viz; cold stenothermal (five species), eurythermal (eight species), and warm stenothermal (20 species). Among the species recorded Polyarthra vulgaris was considered to be cold stenothermal, but the same species was classified as perennial by Yousuf and Qadri [66]. In another detailed hydrobiological study of Anchar lake Balkhi et al. [71] reported 41 species of rotifers, with Asplanchna priodonta being the most dominant species in the rotifer community. Euchlanis dilatata, Proalinopsis sp. and Trichotria tetractis were categorized into eurythermal, while the species like Lecane sp. Monostyla sp. and Mytilina mucronata form warm stenotherms, whereas Notholca acuminata, Colurella sp. and Trichocerca cylindrica were the chief cold stenotherms in the lake. In still another study, Yousuf and Qadri [79] while studying distribution of Polyarthra vulgaris Carlin acclaimed the species to be a perennial, eurythermal (tolerating wide range of temperature $5.6-28.90^{\circ} \mathrm{C}$ ) and attaining only single peak of population (late winter). Distribution of the same species is controlled by a number of abiotic factors such as increase in temperature, $\mathrm{pH}$, carbonates etc. besides some biotic factors especially for Diaphanosoma brachyurum, a cladoceran, that probably competes with the food of Polyarthra vulgaris. Pandit [80] while studying the plankton dynamics in freshwater wetlands of Kashmir (Nowgam, Malgam, Hiagam, Mirgund and Hokarsar] opined that $70-80 \%$ of the rotifer community was constituted by eurythermal species (Keratella sp., Brachionus sp., Lecane sp., Monostyla lunaris, Filina opliensis, Cephalodella sp., Trichocera sp. and Synchaeta pectinata) while less frequent species (Platyias sp. and Diplois sp) were warm stenothermal organisms. Other species, which showed sporadic distribution and prefering cold to moderate temperatures, were Pompholyx sp., Colurella bicuspidata, Monostyla bulla, Notholca acuminata, Gastropus stylifer, Euchlanis diliata, Epiphanes sp. and Polyarthra vulgaris. 
Food and Feeding Habits

Feeding ecology of zooplankton is necessary to understand the pelagic trophic dynamics in aquatic systems [80, 81]. In Kashmir Himalaya detailed studies have been carried out by Pandit and Kaul [82] and Pandit [4, 83] on the trophic structure of some typical wetlands in general and plankton community in particular, drawing attention towards the inter-relationships between the phyto- and zooplankton. All these studies basically focus on the various food and feeding habits of zooplankton as delineated in various food chains and food webs. Rotifers according to the authors have been categorized into herbivores (Polyarthra vulgaris, Epiphanes sp., Keratella cochlearis and Trichocera sp. with the last two species were often seen drilling into an algal filament to suck out its contents), Euchlanis diliata as omnivore and feeding on Pandorina, diatoms and protozoans, and Asplanchna priodonta, Syncheata sp., Pectinata sp., and Gastropus stylifer as raptorial predators (former rotifer shows preference for Brachionus sp. over other available rotifers). Brachionus sp., Keratella valga, K.quadrata, Monostyla sp., Lecane sp., Notholca acuminata, Philiodina sp., Colurella sp., Platyias sp., Diplois sp., Mytilina sp., Pompholyx sp. and Filina sp. were categorized as secondary consumers. They further opined that Keratella cochlearis, B. calyciflorus, Epiphanes sp. and Asplanchna priodonta as pollution tolerant species.

\section{Vertical Migration}

Diel vertical migration (DVM) by zooplankton is a universal feature and well studied behavior in all the freshwater bodies probably represents the biggest animal migration, in terms of biomass, on the planet [84-87]. Till date only two published reports were available regarding the vertical migration of rotifers in Kashmir Himalaya. Khan [70] while studying periodicity of zooplankton in two flood plain lakes (Trigamasar and Naranbagh] inferred that there was a clear periodicity among the rotifers between the upper and bottom layers and showed four times denser population $(5,400$ units/L) in bottom layers than the surface layer (1,375 units/L) of Trigamasar. Yousuf and Mir [60] while studying the vertical distribution in a warm monomictic Manasbal lake of Kashmir recorded 23 species of rotifers from the limnetic zone having trimodal pattern of fluctuations with two distinct peaks in late March and August and the third, a feeble, one in the month of May. They further opined thermal stratification being one of the main causes, besides vertical distribution of gases and nutrients, responsible for the distribution patterns of these animals. The recorded species showed different behaviour in response to thermal stratification. For example Polyarthra vulgaris and Keratella cochlearis, (former being the most dominant species) both prefer metalimnion with perennial behaviour.

\section{Conclusion}

In conclusion, the research on rotifers, making an important component of zooplankton community, needs further detailed exploration in a vast spectrum of freshwater bodies of Kashmir including lakes, wetlands, springs and streams, though scanty and inconsistent information is available on taxonomy, species composition and density of the wheel animalcules. Detailed taxonomic survey based on the species morphology using very recent approaches like SEM techniques and DNA bar coding is the much needed research enabling the limnologists to make a correct and exhaustive identification of the species. The role of the rotifers as biomonitoring tools and an important food source in the aquatic food chains are also other important aspects of the ecology of rotifers.

Acknowledgments Thanks are due to the Director, Centre of Research for Development and Head, Environmental Science, University of Kashmir for providing necessary laboratory facilities.

Open Access This article is distributed under the terms of the Creative Commons Attribution License which permits any use, distribution, and reproduction in any medium, provided the original author(s) and the source are credited.

\section{References}

1. Zutshi DP, Khan MA (1978) On the lake topology of Kashmir. In: Sen DN, Bansal RP (eds) Environmental physiology and ecology of plants. Bishen Singh M.Pal Singh, Dehra Dun, India, p 465-472

2. Pandit AK (1993) Dal lake ecosystem in Kashmir Himalaya: ecology and management. In: Mishra PC, Trivedy RK (eds) Ecology and pollution of indian lakes and reservoirs. Ashish Publishing House, New Delhi, pp 131-202

3. Kaul V, Handoo JK (1989) Studies on the ecology of Kashmir Himalaya. In: Singh JS, Gopal B (eds) Perspectives in ecology. Jagmander Book Agency, New Delhi, India, p 1-48

4. Pandit AK (1999) Trophic structure of plankton community in some typical wetlands of Kashmir, India. In: Mishra SR (ed) Limnological research in India. Daya Publishing House, Delhi110035 p 190-224

5. Kaul AK (1978) Kashmir weather and climate. Inquiry (Coll Edu Srinagar, India) 5:17-36

6. Pandit AK (2002) Freshwater biological resources of Kashmir Himalaya. In: Pandit AK,(ed) Natural resources of western Himalaya. Valley Book House, Srinagar-190006, J\&K p 123-174

7. Dudgeon D, Arthington A, Gessner M, Kawabata Z, Knowler DJ, Lévêque C, Naiman R, Prieur-Richard A, Soto D, Stiassny M, Sullivan C (2006) Freshwater biodiversity: importance, threats, status and conservation challenges. Biol Rev 81:163-182

8. Sladecek V (1983) Rotifera as indicators of water quality. Hydrobiologia 100:169-201 
9. Barnes RSK, Calow P, Olive PJW (1993) The invertebrates: a new synthesis, 2nd edn. Blackwell Scientific Publications, Oxford $582 \mathrm{pp}$

10. Wallace RL (2002) Rotifers: exquisite metazoans. Int Comp Biol 42:660-667

11. Pejler B (1995) Relation to habitat in rotifers. Hydrobiologia 313(314):267-278

12. Sharma BK (2009) Diversity of rotifers (Rotifera, Eurotatoria) of Loktak lake, Manipur North-eastern India. Trop Ecol 50(2):277-285

13. Wallace RL, Snell TW (2010) Rotifera. In: Thorp JH, Covich AP (eds) Ecology and classification of freshwater invertebrates. Elsevier, Oxford, p 173-235

14. Hyman LH (1951) The invertebrates. Acanthocephala, aschelminthes and entoprocta. McGraw-Hill, New York

15. Ricci C, Melone G (2000) Key to the identification of the genera of bdelloid rotifers. Hydrobiologia 418:73-80

16. Segers H (2007) Annotated checklist of the rotifers (phylum Rotifera), with notes on nomenclature, taxonomy and distribution. Zootaxa 1564:1-104

17. Ruttner-Kolisko A (1974) Planktonic rotifers: biology and taxonomy. Die Binnengewässer (Suppl.) 26:1-146

18. Edmondson WT (1992) Freshwater biology, 2nd edition edn. John Wiley \& Sons Inc, USA, p 1248

19. Vanjare A, Pai K (2010) Rotifers from University of Pune (India), with record of Ptygura pedunculata (Edmondson, 1939) (Rotifera: Monogononta) from Oriental region. Turk J Zool 34:417-419

20. Makarewicz JC, Likens GE (1979) Structure and function of the zooplankton community of Mirror Lake, New Hampshire. Ecol Monogr 49:109-127

21. Akinbuwa O, Adeniyi IF (1991) The rotifer fauna of opa reservoir, Ile- Ife Nigeria. J Afr Zool 105:383-391

22. Nogrady T, Wallace R, Snell T (1993) Rotifera: biology, ecology and systematic. In: Dumont $\mathrm{H}$ (ed) Guides to the identification of the micro-invertebrates of the continental waters of the world Vol. 1. SPB Academic Publishing, The Hague, p 1-142

23. Bonecker CC, Lansac-Tôha FA (1996) Community structure of rotifers in two environments of the high Paraná River floodplain (MS), Brazil. Hydrobiologia 325:137-150

24. Zankai N (1984) Predation of cyclops vicinus (copepoda: cyclopoida) on small zooplankton animals in Lake Balaton (Hungary). Arch Hydrobiol 99:360-378

25. Park GS, Marshall HG (2000) The trophic contributions of rotifers in tidal freshwater and estuarine habitats. Estuar Coast Shelf Sci 51:729-742

26. Snell TW, Janssen CR (1995) Rotifers in ecotoxicology: a review. Hydrobiologia 313(314):231-247

27. Allan JD (1976) Life history patterns in zooplankton. Am Nat 110:165-180

28. Wallace RL, Snell TW, Ricci C, Nogardy T (2006) Rotifera: biology, ecology and systematic. In: Segers H, Dumont HJ (eds) Guides to the identification of the microinvertebrates of the continental waters of the world, vol 23. Kenobi Productions, Ghent, and Backhuys Publishers, Backhuys Publishers, Leiden, p 299

29. Sharma BK (1998) Rotifera. In: Alfred JRB, Das AK, Sanyal AK (eds) Faunal diversity of India. Zoological Survey of India, Calcutta, pp 57-70

30. Segers H, Babu S (1999) Rotifera from a high-altitude Lake in Southern India, with a note on the taxonomy of Polyarthra Ehrenberg, 1834. Hydrobiologia 405:89-93

31. Sharma BK, Sharma S (2001) Biodiversity of rotifera in some tropical floodplain lakes of Bramhaputra river basin, Assam (N. E India). Hydrobiologia 446(447):305-313

32. Anderson HH (1889) Notes on Indian rotifera. J Asiat Soc Bengal $58: 345-358$
33. Murray J (1906) Some rotifera of Sikkim Himalaya. J Microscop Soc London 9:637-644

34. Stewart FH (1908) Rotifers and gastrotricha from tibet. Rec Indian Mus Calcutta 2:316-323

35. Edmondson WT, Hutchinson GE (1934) Report on rotatoria: article IX. Yale North India expedition. Mem Conn Acad Art Sci 10:153-186

36. Ahlstrom EH (1940) A revision of the rotatorian genera brachionus and platyias with description of one new species and two new varieties. Bull Am Mus Nat Hist 77:143-184

37. Nayar CKG, Nair KKN (1969) A collection of brachionid rotifers from Kerala. Proc Ind Acad Sci Sec B 69(4):223-233

38. Nayar CKG (1968) Rotifer fauna of Rajasthan. Hydrobiologia $31: 168-185$

39. Naidu KV (1967) A contribution to the rotatorian fauna of South India. J Bombay Nat Hist Soc 64:384-388

40. Vasisht HS, Gupta CL (1967) The rotifer fauna of Chandigarh. Res Bull (N.S.) Punjab Univer 18:495-496

41. Vasisht HS, Battish SK (1971) The rotifer fauna of North India. Lepadella and Colurella. Res Bull (N.S.) Punjab Univer 22:189-192

42. Vasisht HS, Battish SK (1971) The rotifer fauna of North India. Platyias, keratella, anuraeopsis, mytilina and euchlanis. Res Bull (N.S.) Punjab Univer 22:331-337

43. Sharma BK (1976) Rotifers collected from north-west India. Newsl Zool Surv India 2:255-259

44. Sharma BK (1978) Contributions to the rotifer fauna of West Bengal. II. Genus Lepadella Bory de. St. Vincent, 1826. Hydrobiologia 58(1):83-88

45. Sharma BK (1980) Contributions to the rotifer fauna of Orissa, India. Hydrobiologia 70:225-233

46. Sharma BK (1983) The Indian species of the genus Brachionus (Eurotatoria: Monogononta: Brachionidae). Hydrobiologia 104:31-37

47. Sharma BK (1993) Freshwater rotifers (Rotifera: Eurotatoria) from some domestic wells in West Bengal. J Indian Institute of Science 73:463-468

48. Sharma BK (1995). Freshwater rotifers (Rotifera: Eurotatoria). In: Fauna of West Bengal. State Fauna Series 3. Zoological Survey of India, Calcutta, 13: 1-121

49. Sharma BK, Michael G (1980) Synopsis of taxonomic studies on Indian Rotifera. Hydrobiologia 73:229-236

50. Kiefer F (1939) Scientific results of the Yale North India Expedition. Biol. Report Nr. 19: freilebende Ruderfußkrebse (Crustacea Copepoda) aus Nordwest- und Südindien (Pand-schab, Kaschmir, Ladak, Nilgirigebirge). Mem Ind Mus 13:83-203

51. Wanganeo A, Wanganeo R (2006) Plankton diversity in Kashmir Himalayan lakes: an overview. In: Ashwani Wanganeo, Langer RK (eds) Trends in Biodiversity and Aquaculture Daya Publishing House, Delhi-110035, India, p 130-160

52. Pandit AK (2008) Biodiversity of wetlands of Kashmir Himalaya. Proc Natl Acad Sci India B (Pt Spl Issue) 78: 29-51

53. Sharma BK, Sharma S (1987) On some species of the family Notommatidae (Eurotatoria: Monogononta) from North-Eastern India. Bull Zool Surv India 8:177-183

54. Patil CS, Gouder BYM (1989) Freshwater Invertebrates of Dharwad (Karnatak State, India). Prasaranga Karnatak University, Dharwad $144 \mathrm{pp}$

55. Segers H, Sarma SSS, Kakkassery FK, Nayar CKG (1994) New records of Rotifera from India. Hydrobiologia 287:251-258

56. King CE (1972) Adaptation of rotifers to seasonal variation. Ecology 53:408-418

57. Sommer U, Gliwicz ZM, Lampert W, Duncan A (1986) The PEG-model of seasonal succession of planktonic events in fresh waters. Arch Hydrobiol 106:433-471

58. Wanganeo A, Wanganeo R (2006) Variation in zooplankton population in two morphologically dissimilar rural lakes in Kashmir Himalaya. Nat Acad Sci 76(3):222-239 
59. Hutchinson GE (1967) A Treatise on limnology: introduction to lake biology and the limnoplankton, vol II. John Willey \& Sons Inc, New York, p 1115

60. Yousuf AR, Mir MF (1994) Vertical distribution of Rotiferal in warm monomictic lake of Kashmir. J Freshwater Biol 6(2):143-149

61. Das SM (1969) Studies of organic production in high altitudes of lakes of India 1. The general ecology and zooplankton of Kashmir lakes. Kashair Science, Kashmir University, Srinagar 7 (1/2): $1-22$

62. Das SM, Akhtar S (1976) A survey of rotifers of Kashmir with new records of Palaearctic genera and species. Rotifer News 3:9-12

63. Zutshi DP, Subla BA, Khan MA, Wanganeo A (1980) Comparative limnology of nine lakes of Jammu and Kashmir Himalaya. Hydrobiologia 72:101-112

64. Kaul VDN, Fotedar AK, Pandit, Trisal CL (1978) A comparative study of plankton populations in some typical fresh water bodies of Jammu and Kashmir State. In: Sen DN, Bansal RP (eds) Environmental Physiology and Ecology of Plants. B. Singh, M. Pal Singh, Dehra Dun, pp 249-269

65. Zutshi DP, Wanganeo A, Raina R (1980) Limnology of a manmade lake. Geobois 7:320-324

66. Yousuf AR, Qadri MY (1981) Seasonal abundance of rotifera in a warm monomictic lake. J Indian Inst Sci 63:23-34

67. Yousuf AR, Qadri MY (1985) Seasonal fluctuations of zooplankton in Lake Manasbal. Indian J Ecol 12:354-359

68. Yousuf AR, Balkhi MH, Qadri MY (1986) Limnological features of a forest lake of Kashmir. J Zool Soc India 38:29-42

69. Khan MA (1987) Observation on zooplankton composition, abundance and periodicity in two flood-plain lakes of the Kashmir Himalayan valley. Acta Hydrochim Hydrobiol 15(2):167-174

70. Balkhi MH, Yousuf AR, Qadri MY (1987) Hydrobiology of anchar lake. J Comp Phys Ecol 12:131-139

71. Pandit AK, Qadri SS (1990) Floods threatening Kashmir wetlands. J Environ Manag (London) 31(4):299-311

72. Pandit Anil K, Yousuf AR (2003) Rotifer community in some Kashmir Himalayan lakes of varied trophic status. J Res Dev 2:1-12

73. Siraj S, Yousuf AR, Bhat FA, Parveen M (2006) Impact of floating gardens on the water quality and zooplankton community in Dal Lake Kashmir. J Res Dev 6:25-34
74. Wanganeo A, Mir AR, Yousuf AR, Wanganeo R(2008) Seasonal variation of Rotifera population in relation to physico-chemical factors. In: Chishti MZ, Fayaz Ahmad (eds) Science for better tomorrow. University of Kashmir, Srinagar, p 231-236

75. Shah JA, Pandit AK (2013) Relation between physico-chemical limnology and crustacean community in Wular Lake of Kashmir Himalaya. Pak J Biol Sci 16(19):976-983

76. Qadri MY, Yousuf AR (1982) Distribution of anuraeopsis fissa gosse and notholca acuminata ehrn in relation to some physicochemical factors. J Zool Soc India 34:12-20

77. Balkhi MH, Yousuf AR, Qadri MY (1984) Rotifera of Anchar lake during winter and summer. Geobios New Rep 3:163-165

78. Yousuf AR, Qadri MY (1986) Ecology of Polyarthra vulgaris carlin in a warm monomictic lake of Kashmir. J Indian Inst Sci 66:405-410

79. Pandit Ashok K (1998) Plankton dynamics in freshwater wetlands of Kashmir. In: Mishra KD (ed) Ecology of polluted waters and toxicology. Technosci Publications, Jaipur, pp 22-68

80. Turner JT (1984) The feeding ecology of some zooplankters that are important prey items of larval fish. NOAA Tech Rep NMFS 7:1-28

81. Pandit AK, Kaul V (1982) Trophic structure of some typical wetlands. In: Gopal B, Turner RE, Wetzel RG, Whigham DF (eds) Wetlands: ecology and management, part II. Nat Inst Ecol Int Sci Publ, Jaipur, pp 55-82

82. Pandit AK (1995) Interrelationship between phyto- and zooplankton in Indian wetlands. In: Mishra PC, Behera N, Senapati BK, Guru BC (eds) Advances in ecology and environmental sciences. Ashish Publishing House, New Delhi, pp 253-271

83. Buchanan C, Haney JF (1980) Vertical migrations of zooplankton in the arctic: a test of the environmental controls. Am Soc Limnol Oceanogr (Spec Symp) 3:69-79

84. Iwasa Y (1982) Vertical migration of zooplankton: a game between predator and prey. Am Nat 120:171-180

85. Sekino T, Yamamura N (1999) Diel vertical migration of zooplankton: optimum migrating schedule based on energy accumulation. Evol Ecol 13:267-282

86. Hays GC (2003) A review of the adaptive significance and ecosystem consequences of zooplankton diel vertical migrations. Hydrobiologia 503:163-170

87. Perticarrari A, Arcifa MS, Rodrigues RA (2004) Diel vertical migration of copepods in a Brazilian lake: a mechanism for decreasing risk of Chaoborus predation? Br J Biol 64(2):289-298 